\title{
The Treatment of Industrial Waste by Recycling in Tunisia
}

\author{
Lamia Jamel $^{1}$ \\ ${ }^{1}$ Faculty of Economic Sciences and Management of Sousse, University of Sousse, Tunisia \\ Correspondence: Lamia Jamel, Faculty of Economic Sciences and Management of Sousse, University of Sousse, \\ 184 Street of Ahmad Hamza, Sahloul 1 Sousse, Tunisia. E-mail: lajamel@yahoo.fr
}

Received: February 10, 2018; Accepted: February 27, 2018; Published: March 15, 2018

\begin{abstract}
Waste management in Tunisia is currently one of the priorities of environmental protection and is one of the main pillars of sustainable development. Thus, Tunisia has opted for a comprehensive and progressive policy of environmental protection in order to manage with the current state of the object affected by the strong economic growth and the environment rapid urban expansion in recent years. The area of waste management has received attention currently given the quantity produced changes in the multiplicity of forms and aspects of pollution caused by waste, and limited resources used in the field of solid waste management. During this, our research has been devoted to the study of the phenomenon of industrial waste management by recycling in Tunisia. We employ a model based on a time series analysis model for a period of 17 years from 2000 to 2016. Additionally, we estimate the ability to manage industrial waste recycling based on variables related to the business of recycling industrial waste, variables related to the intervention of Tunisia policy in the management of industrial waste recycling and macroeconomic indicators. From the empirical findings, we conclude that the macro-economic indicators have a negative impact on the dependent variable. The variables related to the intervention of Tunisia policy in industrial waste management through recycling have a positive impact and a negative impact depending on the nature of the waste. And finally, the variable relative to the activity of recycling industrial waste TRDI has a positive impact and DIG variable has a negative impact.
\end{abstract}

Keywords: waste, waste management, industrial waste, pollution, recycling, time series

\section{Introduction}

The main objectives of waste management strategies are addressed to health, environmental degradations and economic growth concerns associated with the improper disposal of waste. These issues are a constant concern for countries, municipalities, corporations and individuals worldwide, and the international community at large. As a result, most countries have sought systems and models for use in waste management. These systems are employed by organizations main mission; is the management of waste from economic activities (Chertow et al., 2008).

Bimonte (2002) finds that systems of waste management defined by each country are employed as aids to decision tools for planning, monitoring and optimization of expected following waste management results.

Chen et al. (2011) show that most of these systems have been used in developed economics and for low intensity in developing economics.

In this respect, economic growth can play a significant responsibility in waste management. However, a developed economy can guarantee the survival of an effective system of waste management from different economic activities. With the beginning of the industrial revolution, waste management has become a crucial subject

There was an important increase in industrial and domestic waste posing a threat to human health and the environment degradation. Then, the living conditions of rural areas in England during this time forcing companies to purpose solutions and make important changes. Bruyn et al. (1998) find that the understanding of good hygiene is important to maintain a desired lifestyle.

Note as well that there was a close relationship among economic growth and environmental degradation: as communities grow environmental declines. This trend is clearly demonstrated on graphs of human population, economic growth and environmental indicators.

In economic and environmental fields, the term decoupling is increasingly employed in the context of economic growth and environmental quality. When utilized in this way, it refers to the ability of an economy to grow without incurring a corresponding increase in pressure on the environment. 
In this context, we proceed in this article to examine empirically the management of waste recycling in Tunisia (figure 1). The area of waste management has received attention currently given the quantity produced changes in the multiplicity of forms and aspects of pollution caused by waste, and limited resources employed in the field of solid waste management. Under the terms of the Basic Act on common, the sector has been an important transform reflected in the early 1990s by the implementation of the National Waste Management Programme. This development was followed by a framework law on waste management in 1996, and finally the creation of the National Agency for Waste Management in 2005.

To assess our empirical investigation, we utilize yearly data from 2000 to 2016 for the business of recycling industrial waste, the intervention of Tunisia policy in the management of industrial waste recycling and macroeconomic indicators. Additionally, we estimate the ability to manage industrial waste recycling based on variables related to the business of recycling industrial waste, to the intervention of Tunisia policy in the management of industrial waste recycling and macroeconomic indicators. The empirical results show that the macro-economic indicators have a negative impact on the recycling industrial waste. The variables related to the intervention of Tunisia policy in industrial waste management through recycling have a positive impact and a negative impact depending on the nature of the waste. The variable relative to the activity of recycling industrial waste TRDI has a positive impact and DIG variable has a negative impact.

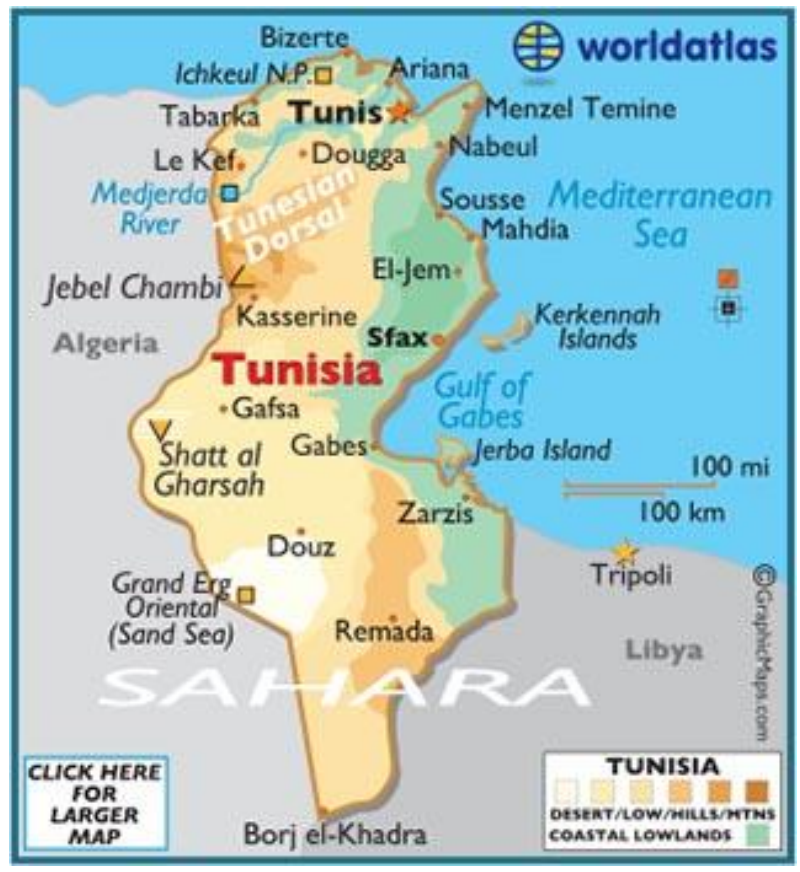

Figure 1. Tunisia Map

Source: NAWN

\section{Literature Review}

The growth of industrial production has led to an increase in the amount of waste of all kinds, which thus appears as a sequel to economic development. The accumulation of waste is also related to shortening the life of the property (Lawrence, 2011).

Recycling appears to be an attractive explanation to the problem of waste from industrial firms since values what was considered fallen and useless (Lyons, 2007). Indeed, the problems of scarcity and that of waste far from being solved by substituting materials or by extending product life are instead often aggravated. Consequently, the recycling policy appears to be the most beneficial solution among other policies including resource conservation, materials substitution and extending product life.

\subsection{Materials Substitution}

Material substitution is to replace a potentially dangerous material with one that appears less problematic to the environment; this is predominantly the case with the so-called synthetic products: rubber and synthetic fibers and plastics (Chertow, 2000). The possibilities of substitution among materials can fight against the shortage of 
resources and can solve the problem of resource supply. This action seems reasonable that may sometimes be desirable, however, it will be problematic to the environment if it leads to the reduction of a scarce resource or augmented extraction of other materials that are not ecological and damaging to our planet.

Indeed, it is indisputable that the appearance of substitutes is brought against the opportunity of resource depletion means, but the result is quite complicated by the information that replacement of materials has numerous limitations (Ajzen, 1991).

It is noted that for such a discussion on the replacement of materials must take into consideration the following limits:

The difficulty of time required for sufficient substitutes must be developed and deployed; switch may sometimes be a holdup over time, which can reason disturbance to the economy. Consequently, many substitutes for some they are available at reasonable prices and can take several decades (Chertow et al. 2008).

The substitution of metals requires a big quantity of energy and consequently elevated costs of energy.

A number of substitutes such as synthetic products are not ecological unlike those they restore and then can be extremely injurious to the environment.

Substitutions metals can cause more negative influences on the environment than those they replace, e.g. aluminum smelter may cause more pollution than their counterpart's tinplate.

Replacements can be obtained from a scarce resource as well. It is not clear that if a resource becomes scarce, its alternate is accessible. It is thus probable for a plurality of raw materials substituent's there among become scarce almost concurrently.

In conclusion, we remark that the material substitution is technically feasible. However, the problems posed by the shortage of some resources and the difficulty of excessive energy consumption and pollution impacts persist and may even worsen the acceptance of this approach to materials substitution.

\subsection{The Extension of Product Life}

Extending the life of the assets as a means to stop waste favors and fight against the reduction of resources.

Certainly, with increased product toughness, it throws less as the need to replace old products decrease (lower replacement rate) which reduces the amount of waste produced. In addition, it avoids the waste of natural resources used to develop the products.

This addition of the life of a product can be done thanks to the repair, or to re-use of the products. It should be noted that the extension of the life of a healthy, which implies modify in the performance of consumers and producers, could measure economic activity.

For example, major exhaust producers who are facing a looming disaster as they have improved the life of their products to their competitors complexity (Grossman and A. B. Krueger, 1995).

Certainly, today's modern goods are manufactured to a shorter life and this is because the producers are interested to augment sales and make the most of profits by growing the rate of substitute goods among consumers.

\subsection{Recycling}

The detail that recycling is currently experiencing an unprecedented development, we must not forget that this movement still exists. Any time, for fear of missing or for reasons of economy, the man recovered and reused materials and products that may be.

The developments of recycling activities are part of an awareness of the damage caused by economic growth. Consequently, it is through the employ of waste from industrial recycling companies trying to address the problems of waste and resource scarcity (Geng et al., 2009).

Additionally, recycling "waste again" usually leads to the production of a different input (case of waste iron and steel steelworks which are straight reused in the production process. Recycling "waste old" can guide to the production of an input (in the case of scrap cars crushed recycled steel production) or an output (if the old paper from which the product recycled paper).

In all cases, recycling can both explain the difficulty of waste accumulation and substitute resources already utilized for virgin resources that can sometimes be non-renewable.

Operations environment friendly recycling can help preserve resources and defend our planet. But, if they are not carried out correctly, recycling operations can produce them even pollution is sometimes resented the pollution from processing virgin materials. 
It should be renowned as well that numerous obstacles may delay the development of recycling and it is consequently essential to optimize this technique to make it even better.

\section{Waste Management in Tunisia}

\subsection{The Management of Municipal Solid Waste and Similar}

The municipal solid waste and similar represents the waste from household electrical and electronic equipment and equipment which, although used for professional purposes or for the needs of associations, are similar to those of households because of their nature and which they are distributed

According to the results assigned by the 2007 estimates by the NAWM (National Agency of Waste Management), the amount of household and parallel waste produced annually is estimated to 2.2 million tones and about 53,000 tones of packaging. These results are derived according to studies on this subject. Really, household waste is characterized by a high level of organic material (68\%) and a high humidity of among $65 \%$ and $70 \%$.

Therefore, according to the information published by the NAWM, the different components of municipal solid waste are reported in Figure 2.

In the context of environmental programs in the brawl against pollution caused by waste, with the sustain of the clean development mechanism of the World Bank, and in the Fund Carbon introduced by the Kyoto Protocol, Tunisia has made the signing of 2 contracts for the sale of $50 \%$ of greenhouse gas emissions from the landfill Jebel Chakir (figure 3) and controlled landfills governorate of Bizerte, Nabeul, Sousse, Monastir, Kairouan, Sfax, Gabes, Medenine and the island of Djerba.
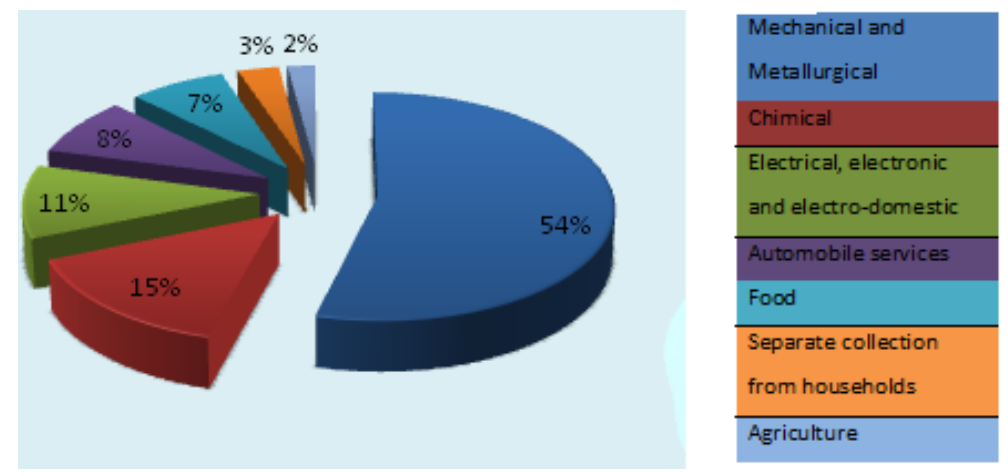

Figure 2. Components of municipal solid waste and similar

\section{Source: NAWN}
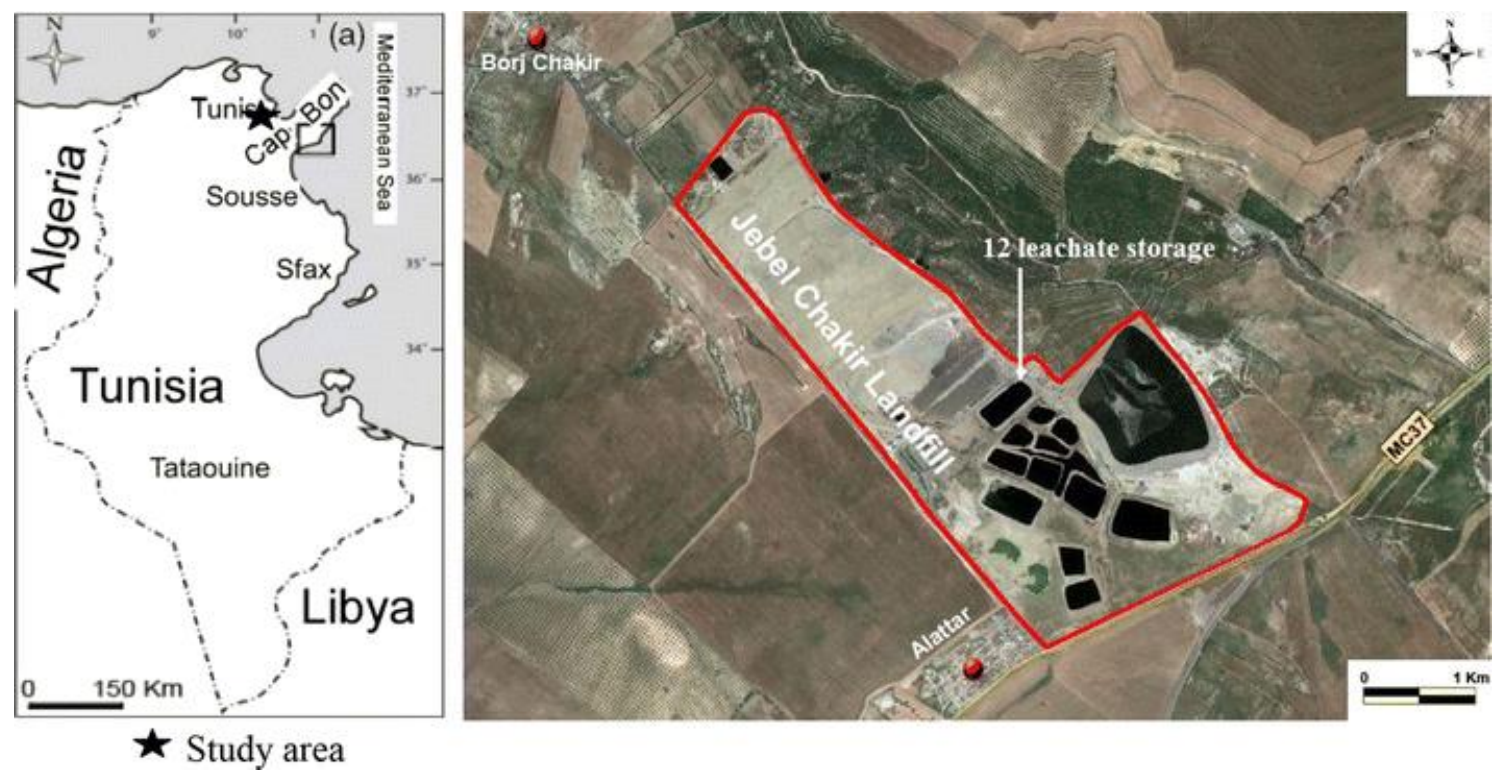

Figure 3. Jebel Chekir in the map 
Though, the amount of gas is 3 million tones and the business is expected to produce about $\$ 8$ million to be employed for the extension of the landfill Jebel Chakir, the financial plan closure and treatment of landfills anarchic and system installation for the extraction and flaring of gas in landfills.

The progress in this program is characterized by the four projects:

- The project of collecting and processing biogas at the controlled Jebel Chakir discharge and continuation of operation and maintenance of collection system and flare operations since November 2008.

- The project of collecting and processing biogas at controlled Bizerte, Gabes and Djerba landfills and continuation of logging operations and maintenance collection system and flare, since August 2010.

- The project of collecting and processing biogas at Sfax and Medenine controlled landfills and continuation of logging operations and maintenance of the collection system and flare, since June 2011.

- In training of tender documents relating to the projects collection and processing biogas at Sousse controlled landfills; Monastir Nabeul.

As the plan of closure and rehabilitation of landfills anarchic Tunisia made:

- The closure and rehabilitation of 9 large uncontrolled discharges.

- The closure and rehabilitation of small and medium anarchic landfills (approximately 140), improving the current state of municipal landfills and participation in the removal of blackheads in cities.

\subsection{The Management of Industrial and Special Waste}

Specific industrial waste is assessed in Tunisia of an annual quantity of 150,000 tons per year. Thus, waste treatment are also quantified an annual quantity of 16000 tones. Indeed, the components of industrial and hazardous waste are presented in figure 4.
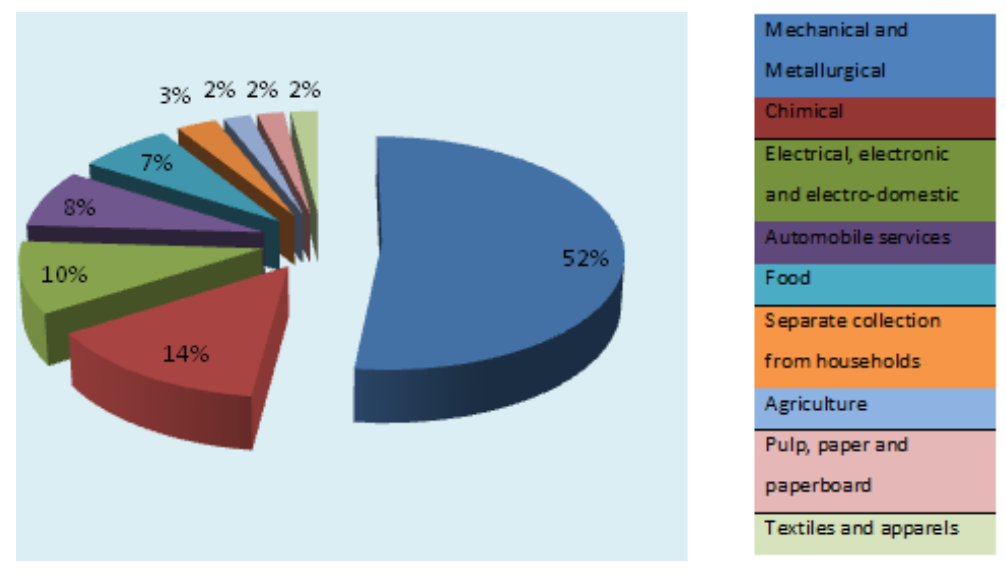

Figure 4. Components of industrial and special waste

Source: NAWN

Tunisia has assumed national policies for the management of industrial and dangerous waste. These strategies are following:

- Establishment of the list of dangerous waste according to their specifications and origins.

- Storage and transportation of dangerous waste according to their individuality and hazards.

- Creating a central dangerous waste management for the whole Tunisian territory.

- Organization of three regional transfers.

- Export of some dangerous waste abroad with reference to international agreements while their management in Tunisia does not define profitability.

These policies are performed by a program of treatment of industrial and dangerous waste:

- Realization of the center of management of industrial and particular waste "Jradou" Zaghouan a cost approximately $\$ 13$ million. The processing center of industrial and special waste Jradou was inaugurated on 5 June 2009. 
- Programming accomplishment of three facilities Reception, Storage and Transfer (IRST) in the North (Bizerte), Centre (Sfax) and South (Gabes), a totality cost of about 22 million dinars. These facilities allowed in 2016 to treat $60 \%$ of industrial and special waste by 2016 .

\subsection{The Management of Recyclable and Recoverable Waste}

The treatment of recyclable and recoverable waste is done by setting up channels. Then, each of them has a specific mission.

\subsubsection{Chain Treatment of Plastic waste "ECOLEF"}

- Totality number of points created is 300 .

- Total points operated by NAWM are 65 with two of them seasonal.

- Number of items privatized in teamwork with the municipalities concerned is 17 .

- Number of points created and is operated by private 228 with:

- 114 operated by tertiary education.

- 9 operated by people with specific needs.

- 18 created in priority delegations employment.

- $\quad$ Number of businesses created as part of the mechanism is 41 .

- Number of units under agreement with the agency recycling is 109, with:

- 70 operated by tertiary education.

- 39 operated by people with specific needs.

- Total number of small businesses (collection, transport and recycling of plastic waste) created by graduates of tertiary education is 231 .

- Amounts collected from the start of the die 2001est 85000 tones.

- Create between 15,000 and 18,000 jobs.

\subsubsection{Die Collection of Employed Batteries and Accumulators "ECOBATTERIES" and "ECOPILES"}

According to reports from the NAWM, the request of the obligatory deposit resumption of accumulators utilized in vehicles, transport and various industrial purposes started on 1 August 2009.

While for employed batteries, collection operations maintain in schools and large spaces in accordance with signed agreements in place.

\subsubsection{Die Collection and Recycling of Used Cooking oil "ECOZIT" and "ECOFILTRE"}

For this sector, 35 small businesses have received the specifications for the compilation of waste and four companies have been approved for establishing primary processing units such waste by filtration.

\subsubsection{Chain Management of Waste Electrical and Electronic Equipment "WEEE"}

This sector is accountable for the management of waste electrical and electronic equipment.

\section{Methodology}

\subsection{Data}

Tunisia contains 24 governorates and 264 municipalities. Well done, communal population represents $65 \%$ of the total population (35\% rural).

In last year's, several studies have been conducted on the waste generated. Thus, data on annual quantities of waste are as follows:

- Household waste 2.2 million tones / year $(0.8 \mathrm{~kg} /$ person / day).

- Specific industrial waste: 150,000 tons / year.

- HCW: 16000 tons / year.

- Packaging waste: 53,000 tons / year (1.4 million units / year).

In this paper, we examine empirically the industrial waste management in Tunisia by recycling. Thus, plans to protect the environment in Tunisia were established in the early 2000s. These programs are designed for waste management for anything their type. Furthermore, we utilize a period of study of 17 years (2000-2016). 
We conduct this work to investigate the phenomenon of industrial waste management in Tunisia over the period of study while using indicators related to the intervention policy of the government, indicators related to recycling activities in Tunisia and economic indicators.

Also, the data sources, which we employ, are:

- The National Statistics Institute of Tunisia (NSIT).

- The Ministry of Environment and Sustainable Development.

- The National Agency for Waste Management (NAWM).

- International Centre for Environnemental Technologies in Tunisia.

- The World Bank.

\subsection{Model}

To examine the phenomenon of management by recycling industrial waste in Tunisia, we will first of all, expose in Table 1 the main indicators that can affect the recycling process.

Table 1. The main determinants government's capacity to recycle industrial waste

\begin{tabular}{|c|c|c|}
\hline & Significant impact & Insignificant impact \\
\hline \multicolumn{3}{|l|}{ Demographic variables } \\
\hline Sex & Burgenmier (2002) and Costa et al. (2010) & Geng et al. (2010) and Jacobsen (2006) \\
\hline Age & $\begin{array}{l}\text { Jahandideh et al. (2009) and Jobert and } \\
\text { Karanfil (2012) }\end{array}$ & $\begin{array}{l}\text { Kennedy et al. (2007) and Liwarska-Bizukojc } \\
\text { et al. (2009) }\end{array}$ \\
\hline Education & Lyons (2005) & Lawrence (2011) and Selden and Song (1994) \\
\hline Household size & Aloysuis and Daihani (2011) & $\begin{array}{l}\text { Grossman and Krueger (1995) and } \\
\text { Burgenmier (2002) }\end{array}$ \\
\hline Location & Lyons (2005) and Selden and Song (1994) & Jacobsen (2006) and Jahandideh et al. (2009) \\
\hline Ethnicity & & Grossman and Krueger (1995) \\
\hline Residential status & Ohnishi et al. (2013) & \\
\hline State of the environment & Burgenmier (2002) & \\
\hline \multicolumn{3}{|l|}{ Economic variables } \\
\hline Household income & $\begin{array}{l}\text { Jahandideh et al. (2009) and Jobert and } \\
\text { Karanfil (2012) }\end{array}$ & $\begin{array}{l}\text { Kennedy et al. (2007) and Selden and Song } \\
\text { (1994) }\end{array}$ \\
\hline The coefficient Engel & $\begin{array}{l}\text { Jahandideh et al. (2009) and Jobert and } \\
\text { Karanfil (2012) }\end{array}$ & \\
\hline GDP & Chertow et al. (2008) & \\
\hline \multicolumn{3}{|c|}{ Taking individual preferences and awareness variables } \\
\hline $\begin{array}{l}\text { The level of environmental } \\
\text { awareness }\end{array}$ & Grossman and Krueger (1995) & \\
\hline $\begin{array}{l}\text { Compliance with laws and } \\
\text { regulations }\end{array}$ & & Chertow et al. (2008) and Lyons (2007) \\
\hline $\begin{array}{l}\text { Environmental values and } \\
\text { beliefs }\end{array}$ & Bruyn et al. (1998) & \\
\hline The habit of recycling & Chen et al.(2011) & \\
\hline $\begin{array}{l}\text { Amenities and recycling } \\
\text { conditions }\end{array}$ & Jahandideh et al. (2009) & \\
\hline Access to recycling program & Jobert and Karanfil (2012) & \\
\hline $\begin{array}{l}\text { The affiliation of the } \\
\text { environment }\end{array}$ & Ajzen (1991) and Ohnishi et al. (2013) & \\
\hline Environmental concerns & Lawrence (2011) and Ajzen (1991) & \\
\hline The economic benefits & Lyons (2007) & \\
\hline
\end{tabular}


To study the factors that affect the amount of waste treated and exploitation rates of recycling facilities, we employ a model as follows:

$$
\begin{gathered}
\mathrm{CAP}_{i}=\alpha_{0}+\alpha_{1} D I G_{i}+\alpha_{2} \text { TRDI }_{i}+\alpha_{3} D V M M_{i}+\alpha_{4} D V C H_{i}+\alpha_{5} D V E E E M_{i}+\alpha_{6} D_{V A A_{i}}+\alpha_{7} D V C S M_{i} \\
+\alpha_{8} D V S A_{i}+\alpha_{9} D V A A I_{i}+\alpha_{10} P_{1} B_{i}+\alpha_{11} C_{P I B}+\varepsilon_{i}
\end{gathered}
$$

Where, $\boldsymbol{\alpha}_{\boldsymbol{0}}$ is a constant, $\boldsymbol{\alpha}_{\boldsymbol{j}}$ represent the coefficients of different variables with $\mathrm{j}=1, \ldots, 11$ and $\boldsymbol{\varepsilon}_{\boldsymbol{i}}$ represent the error term $(i=1, \ldots, 17)$.

- The dependent variable:

$\boldsymbol{C A} \boldsymbol{P}_{\boldsymbol{i}}$ : The government's capacity to recycle industrial waste during the year i (tones / year).

- Independent variables:

$>$ Indicators relating to the recycling activity in Tunisia:

- $\quad \boldsymbol{D I} \boldsymbol{G}_{\boldsymbol{i}}$ : Industrial waste generated in Tunisia through the year i (tones / year).

- $\boldsymbol{T R D I}_{i}$ : The rate of recycling of industrial waste for the year i $(\%)$.

$>$ Indicators related to the intervention policy of the government:

- $\quad \boldsymbol{D V} \boldsymbol{M} \boldsymbol{M}_{\boldsymbol{i}}$ : a dummy variable for the recycling of mechanical and metallurgical waste, whether 1 and 0 if not.

- $\quad \boldsymbol{D V C H}_{\boldsymbol{i}}$ : a dummy variable for the recycling of chemical waste, 1 if yes and 0 if not.

- $\quad \boldsymbol{D V E E E} \boldsymbol{M}_{\boldsymbol{i}}$ : a dummy variable for the recycling of electrical, electronic and electrical appliances waste 1 if yes and 0 if not.

- $\quad \boldsymbol{D} \boldsymbol{V} \boldsymbol{A} \boldsymbol{A}_{\boldsymbol{i}}$ : a dummy variable for the recycling of agro-food waste, whether 1 and 0 if not.

- $\boldsymbol{D V C S M}_{i}$ : a dummy variable for the recycling of waste separate collection from households, 1 if yes and 0 if not.

- $\boldsymbol{D V} \boldsymbol{S \boldsymbol { A } _ { \boldsymbol { i } }}$ : a dummy variable for the recycling of waste automotive services, whether 1 and 0 if not.

- $\boldsymbol{D V A A I}_{\boldsymbol{i}}$ : a dummy variable for the recycling of waste from other industrial activities, whether 1 and 0 if not.

Economic indicators:

- $\quad \boldsymbol{P I} \boldsymbol{B}_{\boldsymbol{i}}$ : The GDP rate in the year i (\%).

- $\boldsymbol{C I P I B}_{\boldsymbol{i}}$ : The contribution of industry to GDP in year i $(\%)$.

Table 2. Descriptive statistics

\begin{tabular}{llllllll}
\hline Variables & Obs & Mean & max & min & Sd & Skewness & Kurtosis \\
\hline CAP & 17 & 7083.333 & 14000 & 2000 & 3892.378 & 0.249231 & 1.738972 \\
DIG & 17 & 132916.7 & 150000 & 100000 & 19477.06 & -0.7509479 & 2.101687 \\
TRDI & 17 & 0.5333333 & 0672 & 0.4 & 0.0976276 & 0.0186706 & 1.681058 \\
DVMM & 17 & 0.3333333 & 1 & 0 & 0.492366 & 0.7071068 & 1.5 \\
DVCH & 17 & 0.3333333 & 1 & 0 & 0.492366 & 0.7071068 & 1.5 \\
DVEEEM & 17 & 0.3333333 & 1 & 0 & 0.492366 & 0.7071068 & 1.5 \\
DVAA & 17 & 0.4166667 & 1 & 0 & 0.5149287 & 0.3380617 & 1.114286 \\
DVCSM & 17 & 0.4166667 & 1 & 0 & 0.5149287 & 0.3380617 & 1.114286 \\
DVSA & 17 & 0.5833333 & 1 & 0 & 0.5149287 & -0.3380617 & 1.114286 \\
DVAAI & 17 & 0.5833333 & 1 & 0 & 0.5149287 & -0.3380617 & 1.114286 \\
GDP & 17 & 2.912658 & 5.333685 & -3.144916 & 2.370479 & -1.413724 & 4.561963 \\
CIPIB & 17 & 30.33873 & 33.83842 & 28.43901 & 1.465741 & 0.9335821 & 3.810863 \\
\hline
\end{tabular}

\section{Empirical Results}

\subsection{Descriptive Statistics}

In this section, we analyze and interpret the different empirical results obtained from the estimates made on the variable cap. Therefore, we specify the type of the model used for estimation is a regression on time series. The 
choice of this type of regression is justified by the existence of only one dimension in the data utilized; this is the time dimension (a period of 17 years). This study focuses on the management of industrial waste in Tunisia during the period 2000 to 2016.

Table 2 summarizes the descriptive statistics for each variable employed in our study. The CAP variable, which measures the ability of Tunisia for the recycling of industrial waste during the period of study, can reach a maximum value of 14,000 tons / year, as its minimum value is 2000 tons / year. The level of risk of the CAP variable which is measured by the standard deviation with a value of 3892,378 . Other statistics on additional variables were showed in Table 2.

We can also indicate the significance of the contribution of industrial activities in the GDP per capita which measured by the variable CIPIB. This variable has a maximum level of $33.83 \%$ and a minimum level of $28.44 \%$. So, industrial activities play a leading role in the economic cycle in Tunisia which reflects the presence of significant amounts of industrial waste responsibility. The contribution of diverse industrial activities in GDP is offered in the figure 5 .
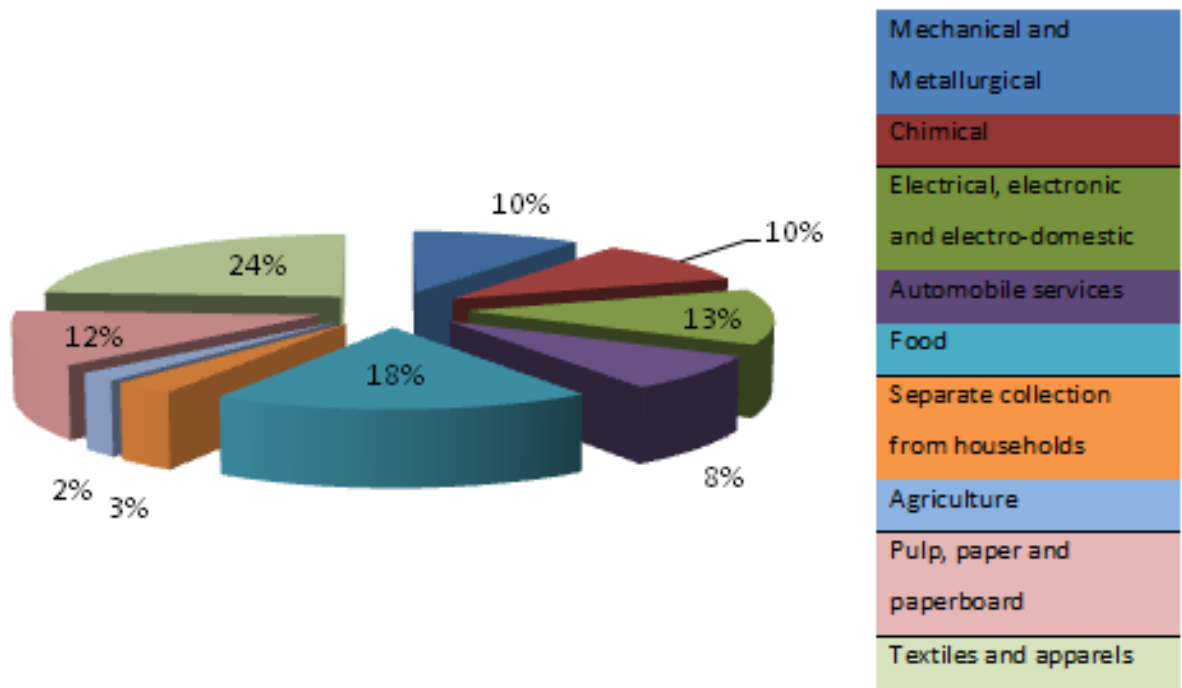

Figure 5. The Share of industry in GDP (year 2016)

In further analysis of the empirical findings, we elaborate a test of correlation among all variables employed in our paper. Table 3 reports the results of test of correlation. Besides, the results of this test show that the majority of Pearson correlation coefficients do not exceed the tolerance limit (0.7), which does not cause problems when estimating the model employed to assess the ability of Tunisia for recycling industrial waste (CAP).

\subsection{Interpretation of the Empirical Results}

The empirical results of the variable CAP are showed in Table 6. This table includes two estimations with the number of explicative variables related to the management of industrial waste recycling in Tunisia.

For the variable CAP, we based our paper on independent variables that are grouped by categories, namely category on the activity of industrial waste recycling in Tunisia, a category on the intervention policy adopted by Tunisia for recycling industrial waste and a class on macro-economic indicators.

In first step, we execute unit root tests to test the stationary of the variables utilized in our study. The results for these tests are presented in the table 4 . This table is reserved to test the stationary of the variables employed in the model to estimate. We use the Augmented Duckey-Fuller test (Duckey and Fuller, 1979) and Philipps-Perron test (Phillips and Perron, 1988). Thus, we remark that only four variables that present the $\mathrm{p}$-value greater than $10 \%$ for both tests Augmented-Duckey-Fuller and Philipps-Perron. These four variables are DVCH, DVEEM, DVCSM and DVAAI. In addition, these variables are Dummy variables. In this case, we have excluded from the model to estimate. Thus, the non-stationary of these variables can present a problem in the estimated model. For other variables, the p-values are less than $10 \%$ and the t-Student calculated values are lower than the t-Student critical threshold of $10 \%$. In this case, we reject $\mathrm{H} 0$ which suppose the presence of unit roots and therefore all these variables are stationary. 
Table 3. Correlation matrix

\begin{tabular}{|c|c|c|c|c|c|c|c|c|c|c|c|c|}
\hline & CAP & DIG & TRDI & DVMM & DVCH & DVEEEM & DVAA & DVCSM & DVSA & DVAAI & GDP & CIPIB \\
\hline CAP & 1.0000 & & & & & & & & & & & \\
\hline DIG & $\begin{array}{l}0.0412 \\
(0.0058) \\
*\end{array}$ & 1.0000 & & & & & & & & & & \\
\hline TRDI & $\begin{array}{l}0.0658 \\
(0.0000) \\
*\end{array}$ & $\begin{array}{l}0.3665 \\
(0.0036) *\end{array}$ & 1.0000 & & & & & & & & & \\
\hline DVMM & $\begin{array}{l}0.0574 \\
(0.0043) \\
*\end{array}$ & $\begin{array}{l}0.6478 \\
(0.0227) \\
* *\end{array}$ & $\begin{array}{l}0.5767 \\
(0.0030) *\end{array}$ & 1.0000 & & & & & & & & \\
\hline DVEEEM & $\begin{array}{l}0.0574 \\
(0.0043) \\
*\end{array}$ & $\begin{array}{l}0.6478 \\
(0.0227) \\
* *\end{array}$ & $\begin{array}{l}0.5767 \\
(0.0030) *\end{array}$ & $\begin{array}{l}0.0700 \\
(0.0000) *\end{array}$ & $\begin{array}{l}0.0700 \\
(0.0000) *\end{array}$ & 1.0000 & & & & & & \\
\hline DVAA & $\begin{array}{l}0.0565 \\
(0.0004) \\
*\end{array}$ & $\begin{array}{l}0.6383 \\
(0.0255) \\
* *\end{array}$ & $\begin{array}{l}0.5632 \\
(0.0003)^{*}\end{array}$ & $\begin{array}{l}0.6367 \\
(0.0007) *\end{array}$ & $\begin{array}{l}0.6367 \\
(0.0007)^{*}\end{array}$ & $\begin{array}{l}0.8367 \\
(0.0007)^{*}\end{array}$ & 1.0000 & & & & & \\
\hline DVCSM & $\begin{array}{l}0.4565 \\
(0.0004) \\
*\end{array}$ & $\begin{array}{l}0.6383 \\
(0.0255) \\
* *\end{array}$ & $\begin{array}{l}0.5632 \\
(0.0003) *\end{array}$ & $\begin{array}{l}0.6367 \\
(0.0007) *\end{array}$ & $\begin{array}{l}0.6367 \\
(0.0007) *\end{array}$ & $\begin{array}{l}0.5367 \\
(0.0007)^{*}\end{array}$ & $\begin{array}{l}0.0230 \\
(0.0000) \\
*\end{array}$ & 1.0000 & & & & \\
\hline GDP & $\begin{array}{l}-0.2277 \\
(0.4767)\end{array}$ & $\begin{array}{l}-0.1668 \\
(0.6043)\end{array}$ & $\begin{array}{l}-0.1636 \\
(0.6115)\end{array}$ & $\begin{array}{l}-0.5719 \\
(0.0520) \\
* * *\end{array}$ & $\begin{array}{l}-0.5719 \\
(0.0520) \\
* * *\end{array}$ & $\begin{array}{l}-0.5719 \\
(0.0520) \\
* * *\end{array}$ & $\begin{array}{l}-0.3666 \\
(0.2412)\end{array}$ & $\begin{array}{l}-0.3666 \\
(0.2412)\end{array}$ & $\begin{array}{l}-0.2538 \\
(0.4260)\end{array}$ & $\begin{array}{l}-0.2538 \\
(0.4260)\end{array}$ & 1.0000 & \\
\hline CIPIB & $\begin{array}{l}0.6413 \\
(0.0246)\end{array}$ & $\begin{array}{l}0.2703 \\
(0.3954)\end{array}$ & $\begin{array}{l}0.6670 \\
(0.0178) \\
* *\end{array}$ & $\begin{array}{l}0.6554 \\
(0.0207) \\
* *\end{array}$ & $\begin{array}{l}0.6554 \\
(0.0207) \\
* *\end{array}$ & $\begin{array}{l}0.6554 \\
(0.0207)^{* *}\end{array}$ & $\begin{array}{l}0.7519 \\
(0.0048) \\
*\end{array}$ & $\begin{array}{l}0.7519 \\
(0.0048) \\
* *\end{array}$ & $\begin{array}{l}0.5422 \\
(0.0686) \\
* * *\end{array}$ & $\begin{array}{l}0.5422 \\
(0.0686) \\
* * *\end{array}$ & $\begin{array}{l}-0.2570 \\
(0.4200)\end{array}$ & 1.0000 \\
\hline
\end{tabular}

Table 4. The test of the unit root

\begin{tabular}{|c|c|c|c|c|c|c|c|}
\hline \multirow{2}{*}{ Variables } & \multirow[b]{2}{*}{ Obs } & \multicolumn{3}{|c|}{ Augmented Dickey-Fuller test } & \multicolumn{3}{|c|}{ Philipps-Perron test } \\
\hline & & t- statistical ${ }^{\mathbf{a}}$ & t-critical $^{b}$ & p-value ${ }^{c}$ & t- statistical ${ }^{\mathrm{d}}$ & t-critical $^{\mathrm{e}}$ & p-value $\mathrm{f}^{\mathrm{f}}$ \\
\hline CAP & 17 & 3343 & 3240 & 0.0664 & 3294 & 2630 & 0.0317 \\
\hline DIG & 17 & 3527 & 3240 & 0.0147 & 2891 & 2630 & 0.0363 \\
\hline TRDI & 17 & 3612 & 3240 & 0.0745 & 3310 & 2630 & 0.0247 \\
\hline DVMM & 17 & 3892 & 2630 & 0.0727 & 2756 & 2630 & 0.0807 \\
\hline DVCH & 17 & -0592 & 2630 & 0.8727 & -0556 & 2630 & 0.8807 \\
\hline DVEEM & 17 & -0592 & 2630 & 0.8727 & -0556 & 2630 & 0.8807 \\
\hline DVAA & 17 & 2739 & 2630 & 0.0365 & 2700 & 2630 & 0.0467 \\
\hline DVCSM & 17 & -0739 & 2630 & 0.8365 & -0700 & 2630 & 0.8467 \\
\hline DVSA & 17 & 3108 & 2630 & 0.0119 & 3061 & 2630 & 0.0302 \\
\hline DVAAI & 17 & 1108 & 2630 & 0.7119 & 1061 & 2630 & 0.7302 \\
\hline GDP & 17 & 2958 & 2630 & 0.0684 & 2872 & 2630 & 0.0969 \\
\hline CIPIB & 17 & 2717 & 2630 & 0.0225 & 2731 & 2630 & 0.0154 \\
\hline
\end{tabular}


${ }^{a}$ This is the calculated t-Student test for unit root by ADF value method.

${ }^{\mathrm{b}}$ This is the critical value of Student's t-test for the unit root by the ADF method.

${ }^{\mathrm{c}}$ This is compared to the threshold value of $10 \% \mathrm{p}$-value.

${ }^{\mathrm{d}}$ This is the calculated t-Student test for unit root by Philipps-Perron method value.

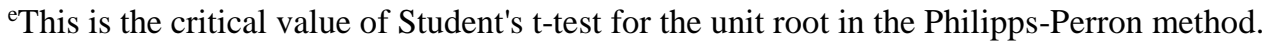

${ }^{\mathrm{f}}$ This is compared to the threshold value of $10 \% \mathrm{p}$-value.

Also, we utilize the technique Breuch-Pagan- for testing of heterosciedasticity. This test allows us to check if the variance of the variables used in our study is constant or not. According to the results of this test presented in Table 5 , we remark that the variance is constant since the probability of chi2 is greater than $10 \%$, consequently we accept the null hypothesis H0 which the variance is constant. In addition, we process technology Ramsey for testing omission of relevant independent variables. This test allows us to check if there are omitted variable or not. Based on the results of this test, we conclude that there is no omitted variable which Fischer probability greater than $10 \%$, consequently we accept the null hypothesis $\mathrm{H} 0$ there is no omitted variable in the estimated model.

Table 5. The test of Breuch Pagan-test and Ramsey

\begin{tabular}{|c|c|c|c|}
\hline \multicolumn{4}{|c|}{ Of hétérosciedasticité Test (Test Breuch-Pagan) } \\
\hline $\operatorname{chi} 2(1)$ & 0.19 & prob>chi2 & 0.6607 \\
\hline \multicolumn{4}{|c|}{ Test omission of explanatory variables (Test Ramsey } \\
\hline $\mathrm{F}(3,1)$ & 2.89 & Prob> F & 0.4023 \\
\hline
\end{tabular}

After presentation various tests mentioned above, we precede the estimation of the model employed in our paper. The results of estimation are shown in Table 6.

Table 6. Estimation of the variable CAP

\begin{tabular}{|c|c|c|}
\hline \multicolumn{3}{|l|}{ Dependent variable: CAP } \\
\hline & Estimation 1 & Estimation 2 \\
\hline Period of study & $2000-2016$ & $2000-2016$ \\
\hline Independent variables & $\begin{array}{l}\text { Coefficients } \\
\text { (T-Student) }\end{array}$ & $\begin{array}{l}\text { Coefficients } \\
\text { (T-Student) }\end{array}$ \\
\hline DIG & $\begin{array}{l}-.005644 \\
(-1.16)\end{array}$ & $\begin{array}{l}-.0022296 \\
(-1.05)\end{array}$ \\
\hline TRDI & $\begin{array}{l}39875.18 \\
(4.51) * \\
\end{array}$ & $\begin{array}{l}38608.86 \\
(2.28) * * \\
\end{array}$ \\
\hline DVMM & & $\begin{array}{l}-1018.372 \\
(-0.37) \\
\end{array}$ \\
\hline DVAA & & $\begin{array}{l}795.6958 \\
(1.34)\end{array}$ \\
\hline DVSA & & $\begin{array}{l}208.8219 \\
(1.10)\end{array}$ \\
\hline GDP & $\begin{array}{l}-129.1342 \\
(-1.79) * * *\end{array}$ & $\begin{array}{l}-179.5199 \\
(-1.82) * * *\end{array}$ \\
\hline CIPIB & $\begin{array}{l}-101.7592 \\
(-3.25) *\end{array}$ & $\begin{array}{l}-104.4706 \\
(-2.18) * * *\end{array}$ \\
\hline CONS & $\begin{array}{l}-9969.876 \\
(-0.86)\end{array}$ & $\begin{array}{l}-9633.213 \\
(-0.47)\end{array}$ \\
\hline Number of obs & 17 & 17 \\
\hline Probability of Fisher & Prob $>F=0.0002$ & Prob $>F=0.0235$ \\
\hline The value of Fisher & $F(4,7)=26.63$ & $F(7,4)=9.40$ \\
\hline $\mathrm{R}$ & 0.9383 & 0.9427 \\
\hline $\mathrm{R}^{2}$ adjusted & 0.9031 & 0.8424 \\
\hline $\begin{array}{ll}\checkmark & \text { The values in paren } \\
\checkmark & \text { Significant at a thre }\end{array}$ & $\begin{array}{l}\text { eses are t-Student v } \\
\text { old value }(*) 1 \% \text {; }\end{array}$ & $\begin{array}{l}\text { s. } \\
5 \% \text { and }(* * *) 10 \% \text {. }\end{array}$ \\
\hline
\end{tabular}


The test of significance of the model is based on the probability of Fisher. We remark that all probability of Fisher are less than $5 \%$ in the estimation of the variable CAP; Prob> F $=0.0002$ for the first estimation and Prob> F = 0.0235 for the second estimation. Therefore, we can conclude that the estimated models are globally significant.

Consequently, we show that the coefficient of determination $R^{2}$ is equal to 0.9383 in the first estimation and 0.9427 in the second estimation; therefore the estimated models are characterized by a good linear fit.

In the first estimation, we estimate the dependent variable CAP based on indicators related to the activity of industrial waste recycling in Tunisia and macro-economic indicators.

Based on the results of the first estimate, we remark that there are three significant variables.

We found that the variable TRDI which measures the rate of recycling of industrial waste in Tunisia has a significant and positive impact on the dependent variable CAP which defines the ability of Tunisia to recycle and manage industrial waste. This impact is significant at the $1 \%$ level and a value of $t-S t u d e n t$ equal to (4.51).

The growth of GDP has a significant and negative impact on the CAP variable to a threshold of $10 \%$ and a value of t-Student (-1.79). This is explained by the information that the growth of GDP is justified by the augmented industrial activity and consequently the presence of enormous amounts of industrial waste. Since the capability to Tunisia for recycling this type of waste is limited. So, GDP will negatively influence the aptitude of recycling industrial waste.

The third significant variable is the variable CIPIB. This variable indicates the contribution of industrial activities in the GDP. We remark that this variable has a significant and negative influence on the dependent variable CAP to a threshold of $1 \%$ and a value of t-Student (-3.25). Additionally, over the contribution of industrial activities in GDP is rising the capability of Tunisia to recycle industrial waste reduces.

In this case, Tunisia is necessary to implement strategy intervention to augment its aptitude to recycle industrial waste. This was the purpose of the second estimation in which we incorporated indicators related to intervention strategy adopted by Tunisia to develop its ability to recycle industrial waste.

In the second estimation, we remark that there are three variables that have an important impact on the variable CAP and other variables have an unimportant impact on the dependent variable CAP.

Then, we found that the variable TRDI which defines the rate of recycling of industrial waste in Tunisia has a significant and positive influence on the dependent variable CAP which represents the capability of Tunisia to recycle and manage industrial waste. This influence is significant at the 5\% level and a value of t-Student of (2.28).

The growth rate of GDP has a significant and negative influence on the dependent variable CAP for a threshold of $10 \%$ and a value of t-Student (-1.82). This is explained by the detail that GDP rate is justified by the augmented industrial activity and consequently the presence of enormous amounts of industrial waste. Since the capacity to Tunisia for recycling this type of waste is limited. Therefore, GDP will negatively influence the capability of recycling industrial waste.

The third significant variable is the variable CIPIB. This variable represents the contribution of industrial activities in the GDP rate. We remark that this variable has a significant and negative influence on the dependent variable CAP to a threshold of $10 \%$ and a value of t-Student (-2.18). Besides, over the contribution of industrial activities in GDP rate is growing the capability of Tunisia to recycle industrial waste decreases.

Finally, the variables related to the intervention policy applied by Tunisia to improve its aptitude to recycle agrofood waste (DVAA) and waste automotive services (DVSA), we conclude that they have a positive influence on the capacity of management and recycling industrial waste. This positive consequence is justified by the creation of specialized companies in the management and recycling of this type of waste. These programs have been created on 2005 .

While, the third variable which measures the political policy adopted by Tunisia for the management of mechanical and metallurgical waste (DVMM) has a negative impact on the dependent variable CAP.

Indeed, we can conclude that the management of industrial waste recycling in Tunisia is based primarily on the adopted strategy interventions such as the creation of specialized companies in the recycling of industrial waste.

\section{Conclusion}

Waste management has attracted the attention of existing authorities in Tunisia and it is one significant objective to guarantee the protection of the environment and one of the most important axes of sustainable development. 
Thus, Tunisia adopts several strategy guidelines in policies of socio-economic growth in order to meet the challenges of environmental protection that we refer to the report of the National Agency for Waste Management of Tunisia in 2012.

In this alignment, we develop this paper to investigate empirically the management of industrial waste recycling in Tunisia. In fact, this paper was devoted to an empirical investigation on the management of industrial waste recycling in Tunisia.

Besides, this paper was reserved to the examination of the phenomenon of industrial waste management by recycling in Tunisia. We employ a regression model of time series. We estimate a model that expresses the capability of Tunisia for the management of industrial waste throughout recycling. We utilize as predictors of variables related to the activity of recycling industrial waste, variables related to the intervention of Tunisia policy in the management of industrial waste through recycling and macro-indicators.

According to the results, we found that the macro-economic variables have a negative influence on the dependent variable. Then, the over contribution of economic activities in GDP is rising the capability of Tunisia to recycle industrial waste reduces. Also, the variables related to the intervention of Tunisia strategy in industrial waste management through recycling have a positive influence and a negative effect depending on the nature of the waste. Finally, the variable relative to the activity of recycling industrial waste TRDI has a positive effect and DIG variable has a negative influence.

Furthermore, the suitable management of industrial waste recycling is based on the nature of the involvement of Tunisia for recycling industrial waste strategies.

\section{References}

Ajzen, I. (1991). The theory of Planned behavior. Organizational Behavior and Human Decision Processes, 50(2), 179-211.

Aloysuis, V., \& Daihani, D. (2011). Closing the gap waste in Indonesia. Harnessing industrial waste to Prevent pollution and conserves non-renewable resources, Working Paper, No. 29.

Bimonte, S. (2002). Information access, income distribution, and the environment Kuznets Curve. Ecological Economics, 41, 145-156.

Bruyn, S. M., Van den Bergh, J. C. J. M., \& Opshoor, J. B. (1998). Economic growth and emissions: Reconsidering the empirical environmental Kuznets curves of BASIS. Ecological Economics, 25, 161-175.

Burgenmier, B. (2002). Ecological and social principles of the market. Economica.

Chen, X., Xi, F. M., Geng, Y., \& Fujita, T. (2011). The potential environmental gains from recycling waste plastics. Transferring simulation of recycling and recovery technologies to Shenyang, China. Waste Management, 31, 168-179.

Chertow, M. R. (2000). Industrial symbiosis: literature and taxonomy. Annual Review of Energy and the Environment, 25, 313-337.

Chertow, M., Ashton, W., \& Espinosa, J. (2008). Industrial symbiosis in Puerto Rico. Environmentally related agglomeration economies. Regional Studies, 42(10), 1299-1312.

Chertow, M., Ashton, W., \& Espinosa, J. (2008). Industrial symbiosis in Puerto Rico. Environmentally related agglomeration economies. Regional Studies, 42(10), 1299-1312.

Costa, I., Massard, G., \& Agarwal, A. (2010). Waste management policies for industrial symbiosis development. Case studies in European countries. Journal of Cleaner Production, 18(8), 815-822.

Decree No. 2000-2339 of 10 October 2000 fixing the list of hazardous waste.

Decree No. 2001-843 of 10 April 2001 amending Decree No. 97-1102 of 2 June 1997 laying down the terms and conditions for taking back and managing the packaging bags and packaging used.

Decree No. 20053395 of 26 December 2005 laying down the terms and conditions for the collection of used batteries and batteries.

Decree No. 2005-1156 of 12 April 2005 amending Decree No. 2004-1191 of 25 May 2004 establishing the list of products exempted from the tax for the protection of the environment.

Decree No. 2005-2317 of 22 August 2005 establishing a national waste management agency and setting out its mission, its administrative and financial organization, and the modalities of its operation. 
Decree No. 2007-13 of 3 January 2007, laying down the conditions and methods for the management of sludge from wastewater treatment works for use in agriculture.

Decree No. 2008-2565 of 7 July 2008 amending and supplementing Decree No. 2002-693 of 1 April 2002 on the terms and conditions for taking back lubricating oils and used oil filters and their management.

Decree No. 2008-2745 of 28 July 2008 laying down the conditions and procedures for waste management of health activities.

Decree No. 92-1445 of 27 July 1992 on the publication of the Bamako Convention on the Prohibition on the Importation into Africa of Hazardous Wastes and on the Control of Transboundary Movements and the Management of Hazardous Wastes Produced in Africa.

Decree No. 93-1429 of 23 June 1993 suspending customs duties and value added tax due on imports and the domestic system on garbage collection equipment and equipment acquired by the companies exercising on behalf of local authorities.

Decree No. 93-1614 of 2 August 1993 suspending the value added tax due on the operations of admission to public landfills, treatment and destruction of household waste.

Decree No. 95-2680 of 25 December 1995 on the publication of the Basel Convention on the Control of Transboundary Movements of Hazardous Wastes and Their Disposal, adopted at Basel on 22 March 1989.

Dickey, D. A., \& Fuller, W. A. (1979). Distribution of the Estimators for Autoregressive Time Series with a Unit Root. Journal of the American Statistical Association, 74(366), 427-431.

Geng, Y., Fujita, T., \& Chen, X. (2010). Evaluation of innovative municipal solid waste management through urban symbiosis. A case study of Kawasaki. Journal of Cleaner Production, 18(10-11), 993-1000.

Government Decree No. 2015-786 of 9 July 2015 laying down the conditions and methods of management of used tires.

Grossman, G. M., \& Krueger, A. B. (1995). Economic growth and the environment. Quarterly Journal of Economics, 110, 353-377.

Jacobsen, N. B. (2006). Industrial symbiosis in Kalundborg, Denmark ea quantitative assessment of Economic and environmental aspects. Journal of Industrial Ecology, 10(1-2), 239-255.

Jahandideh, S., Asadabadi, E. B., Askarian, M., Movahedi, M. M., Hosseini, S., \& Jahandideh, M. (2009). The use of artificial neural networks and multiple linear regression to predict rate of medical waste generation. Waste Management, 29(11), 2874-2879.

Jobert, T., \& Karanfil, F. (2012). Formation and deformation of the Environmental Kuznets Curve for CO2 emissions. Innovations, 37, 11-26.

Joint Order of the Ministers of the Environment and Sustainable Development, Finance and Trade and Handicrafts of April 23, 2008, setting the terms and the amount of the mandatory deposit of the recovery of used batteries used in the means transport and for various industrial purposes.

Kennedy, C., Cuddihy, J., \& Engel-Yan, J. (2007). The changing metabolism of cities. Journal of Industrial Ecology, 11(2), 43-59.

Law $n{ }^{\circ}$ 96-41 of June 10, 1996 relating to waste and the control of their management and disposal.

Law No. 2001-14 of 30 January 2001, simplifying the administrative procedures relating to authorizations issued by the Ministry of the Environment and Regional Planning in the areas of its competence.

Lawrence, E. (2011). Must he discourage decoupling? Observations and Economic Diagnosis, 123, 235-257.

Liwarska-Bizukojc, E., Bizukojc, M., Marcinkowski, A., \& Doniec, A. (2009). The conceptual model of an ecoindustrial park based upon ecological relationships. Journal of Cleaner Production, 17(8), 732-741.

Lyons, D. (2005). Integrating waste, manufacturing and industrial symbiosis. Year analysis of recycling, remanufacturing and waste treatment firms in Texas. Local Environment, 10(1), 71-86.

Lyons, D. I. (2007). A spatial analysis of loop closing Among recycling, remanufacturing, and waste treatment firms in Texas," Journal of Industrial Ecology, vol. 11, no. 1, pp. 43-54, 2007.

Ohnishi, S., Fujita, T., Chen, X., \& Fujii, M. (2013). Econometric analysis of the performance of recycling projects in Japanese Eco-Towns. Journal of Cleaner Production, 33, 217-225.

Order of the Minister of the Environment and Sustainable Development of 23 March 2006 establishing a hazardous 
waste treatment unit and a reception, storage and transfer center.

Order of the Minister of the Environment and Sustainable Development dated 17 January 2007 on the approval of the specifications setting out the conditions and procedures for carrying out the activities of collection, transport, storage, treatment, recycling and recovery of non-hazardous waste.

Order of the Minister of the Environment and Sustainable Development of July 11, 2008, amending the Order of October 11, 2005 relating to administrative services provided by the services of the Minister of Environment and Sustainable Development and the conditions of their grant.

Order of the Minister of the Environment and Sustainable Development dated 30 June 2009 amending the Order of 11 October 2005 concerning administrative services provided by the services of the Minister of the Environment and Sustainable Development and the conditions for granting them.

Phillips, P. C. B., \& Perron, P. (1988). Testing for a Unit Root in Time Series Regression. Biometrika, 75(2), 335346.

Selden, T. M., \& Song, D. S. (1994). Environmental quality and development: Kuznets curve is there a for air pollution emission? Journal of Environmental and Economic Management, 27, 147-162.

\section{Copyrights}

Copyright for this article is retained by the author(s), with first publication rights granted to the journal.

This is an open-access article distributed under the terms and conditions of the Creative Commons Attribution license (http://creativecommons.org/licenses/by/4.0/). 